\title{
STUDY ON THE DUCKS FATTY LIVER PRODUCTION UNDER THE EGYPTIAN CONDITIONS
}

\author{
A.A. El-Fiky(1), G.A. Zanaty ${ }^{(1)}$, W.A.H. Ali $^{(2)}$ and A.A.F. Dahrouj ${ }^{(2)}$ \\ (1) Poultry and Fish production Dept., Fac. of Agric., Menoufia Univ., Egypt. \\ (2) Department of Rabbit Breeding Research, Animal Prod. Res. Inst., Agric. Res. Center, \\ Ministry of Agric., Dokki, Giza, Egypt. \\ Received: Nov. 17,2018 \\ Accepted: Nov. 26,2018
}

\begin{abstract}
A total number of one hundred and eight of both Mulard and Muscovy drakes at 12 weeks of age were individually weighed, wing banded and divided randomly into three groups of three replicates, each of six birds. Average of initial body weight of drakes was similar among all groups $(\bar{x})$. Drakes of the first group were fed ad-lib the same ration of the force feeding. The second group fed the force feeding ration without any added enzyme, while the third group was fed the force feeding rations plus Avizyme 1502 enzyme $0.05 \%$. The results showed that Mulard ducks were highly significant in all carcass traits studied (final live body weight, and percentages of carcass, liver, total giblets and edible parts) than Muscovy ducks. The ether extract percentage was insignificant in meat of the Mulard ducks compared with Muscovy ducks, while, the moisture, crude protein and ash percentage were significantly higher in Mulard ducks when compared to Muscovy ducks. Liver of Mulard ducks contained highly significant moisture, crude protein and ash percentages compared to liver of Muscovy ducks. however, liver of Muscovy ducks contain highly significant ether extract percentage compared to liver of Mulard ducks. Liver of Muscovy ducks was highly significant in LDL $(\mathrm{mg} / \mathrm{dl})$ and cholesterol $(\mathrm{mg} / \mathrm{dl})$ and insignificant in total lipids weight $(\mathrm{mg} / \mathrm{dl})$, triglycerides ( $\mathrm{mg} / \mathrm{dl})$ and HDL $(\mathrm{mg} / \mathrm{dl})$ compared to Mulard duck. Blood plasma for Mulard ducks was highly significant in total protein (g/dl), albumin (g/dl), globulin (g/dl), A/G ratio and insignificant in LDL (mg/dl) and AST (U/L) compared to the Muscovy ducks. On contrary, blood plasma of Muscovy ducks was highly significant in total lipids (mg/dl), cholesterol (mg/dl), triglycerides (mg/dl), HDL (mg/dl), glucose (mg/dl) and insignificant in ALT(U/L), compared to Mulard duck.

Conclusively, Mulard ducks are suitable for force feeding than Muscovy ones to achieve a fast increase in body weight in a short time. Also, to have a high quality of fatty liver which have a high marketing value indoors and outdoors
\end{abstract}

Key words: Muscovy ducks, Mulard ducks, Foie gras,blood,liver .

\section{INTRODUCTION}

Developing countries included Egypt are often suffered from protein deficiency. This is due to two main factors. The first is the small number of existing farm animals as compared to rapid growth of human population, and the second is the low productive and reproductive capabilities of these animals (Rowida et al., 2010). Protein of animal source are very important for humans, because of their high nutritive value especially their contents of essential amino acids. The demand for animal protein is rising worldwide, however the supply is not sufficient to cover their demand. This has lead to a nutritional insufficiency especially in classes if people who are suffering from low incomes FAO STAT (2009).

Force-feeding of some waterfowl species induces a form of obesity characterized by dramatic hepatic steatosis (foie gras) induced by a strong 
accumulation of lipids in the liver. The hepatic weight may increase more than 10fold in less than 2 weeks and account for up to $10 \%$ of the body weight (Hermier et al., 1994). Forced-feeding is a very old practice, first recorded in ancient Egypt, (The first incitation of geese being forcefed comes from Saqqarah in Egypt, with representations of the practice in paintings found in a tomb dated at $2500 \mathrm{BC}$ ) but until the 1950's foie gras production remained somewhat limited in volume (Guemene and Guy, 2004). The future of this production is uncertain, at least in Europe. Indeed, although a number of experimental approaches have shown that there is no scientific evidence that validates such adverse comment, this procedure is highly criticized in terms of animal welfare (Guemene and Guy, 2004).

The goal of the present study is to :

1- Investigate the effect of ducks breed (Muscovy and Mulard) and using avizyme enzyme with force feeding on productive performance traits (live body weight, carcass traits), foie gras weight, liver and meat chemical composition and some blood biochemical parameters after overfeeding period under Egyptian condition .

2- Also study the effect of using avizyme enzyme in force feeding.

\section{MATERIALS AND METHODS}

This experiment work was carried out at El-Serw Station, for Water Fowl Research, Animal Production Research Institute, Agricultural Research Center, Ministry of Agriculture, Giza, Egypt. The experiment was carried out during 2014.

\section{Birds, diet and treatments:}

A total number of one hundred and eight of both Mulard and Muscovy drakes at 12 weeks of age were individually weighed; wing banded and divided randomly into three groups of three replicates, each of six birds. Average of initial body weight $(\bar{x})$ of drakes was almost similar among all groups. Drakes of the first group were fed ad-lib the same ration of the force feeding. The second group fed the force feeding ration without any added enzyme, while the third group was fed the force feeding rations plus Avizyme enzyme $0.05 \%$ respectively. Avizyme is a commercial enzyme preparation which contains alfa amylase (300 IU/g), protease (400 IU/g) and exylanase (400 IU/g).

The procedure of pre-force-feeding (continued for ten days to prepare ducks for force feeding period) has three objectives: Increase "crop" size, which is poorly developed in waterfowl species. Stimulation of digestive secretions necessary for the assimilation of a large amount of food. Increase the volume of the digestive tract to initiate metabolic adaptation to force feeding.

Diet composition: For forced fed groups: birds crammed for 14 days with a carbohydrate-rich diet, a high energy diet (HED). The composition of the force feeding diet is illustrated in Table 1. Moreover, the final mixture consisted of 2/3 feed and 1/3 water.

Amount of feeding: Ducks were force-feded twice a day at $8^{\text {am }}$ and $8^{\mathrm{pm}}$ for two weeks (14 days). Ducks are crammed with $300 \mathrm{~g}$ of food at the first of force feeding rising gradually to about $450 \mathrm{~g}$ at the end of force feeding (before they are slaughtered). Each bird was fed on the experimental diet during the two weeks 28 meals as follows for Muscovy and Mulard. The ducks were fed according to Table 2.

Feeding method: Feed ingredients were weighed on dry bases then mixed with $50 \%$ water and final mixture was reweighed. Feed for each bird was introduced to bird crop through Manuel screw dispenser. 
Table 1: Composition of the force feeding diets used in force feeding period.

\begin{tabular}{lc}
\multicolumn{1}{c}{ Ingredients } & $\begin{array}{c}\text { Force feeding Period } \\
(12-14 \text { Wks })\end{array}$ \\
\hline Yellow corn & 98.90 \\
Sodium chloride (Nacl) & 0.30 \\
Plant oil & 0.50 \\
Mineral premix & 0.15 \\
Vitamin premix & 0.15 \\
\hline Total & 100.00 \\
\hline
\end{tabular}

Table 2: Doses of force feeding diets(12-14 wks).

\begin{tabular}{lcc}
\hline Number of meals & $\begin{array}{c}\text { Amount intake/meal } \\
\text { (G/bird). }\end{array}$ & Total amount (Kg/bird) \\
\hline $1-7$ & 300 & 2.100 \\
$8-14$ & 350 & 2.450 \\
$15-21$ & 400 & 2.800 \\
$22-28$ & 450 & 3.150 \\
\hline Total & $--\cdots$ & 10.500 \\
\hline
\end{tabular}

\section{Flock management of ducks:}

Birds were weighed before and after force-feeding; body weight gain, feed consumption and feed conversion ratio (g feed consumed/ $g$ weight gain) of the ducks were calculated during the experimental period. At 14 weeks of age, three birds from each experimental treatment were weighed and slaughtered by slitting the jugular vein, then scalded and de-feathered. Carcasses were manually eviscerated and weighed. Liver, heart, gizzard, digestive tract and abdominal fat were removed and their relative percentages to live body weight were estimated. Also, chemical determination of moisture, crude protein (C.P), ether extracts (E.E) and ash was carried out in diet and meat according to the standard methods of the Association of Official Analytic Chemists A.O.A.C. (1995).

\section{Biochemical parameters:}

Blood samples were collected afternoon from nine birds into heparinzed test tubes from each experimental treatment at 14 weeks of age. Each blood sample was centrifuged immediately at the speed of 3000 r.p.m. for 15 minutes; then the plasma was obtained by centrifugation at 3000 r.p.m / min for 15 minutes to get plasma which was kept at $-15^{\circ} \mathrm{C}$ until the chemical analysis. Plasma total protein, albumin,albumin/ globulin ratio, glucose, total lipid, total cholesterol, high density lipoprotein (HDL), low density lipoprotein (LDL) triglycerides and transaminase enzymes activities (ALT and AST) were determined color metrically using available commercial kits purchased from Diamond Diagnostics Company. 
Liver chemical analysis:

Liver samples were taken at 14 weeks of age (at the end of force feeding period) to measure water, ash, fats and protein. Determination of moisture, crude protein (C.P), ether extract (E.E) and ash were carried out in liver according to the standard methods of the Association of Official Analytic Chemists (A.O.A.C., 1995).

Liver samples were taken at 14 weeks of age were characterized for total lipids. The method of Floch et al. (1990) was conducted for lipid extraction from samples using chloroform methanol (2:1 VIV) to extract the lipids. The lipids in chloroform were dried over anhydrous sodium sulfate, and then the solvent was removed by heating at $60{ }^{\circ} \mathrm{C}$ under vacuum. After extraction the lipids (\%) total lipid, tri-glycerides, Cholesterol, LDL and HDL levels were determined calorimetrically on spectrophotometer using the suitable commercial Kits (Made in Egypt, Diamond Company).

\section{Statistical analysis:}

Data were analyzed by the least squares analysis of variance using the General Linear Models procedure of the statistical analysis model (SAS, 2001).

The statistical model was as follows: $Y_{i j k}=\bar{x}+T_{i}+B_{j}+T B_{i j}+E_{i j k}$

Where: $Y_{\mathrm{ijk}}=$ All observation; $\overline{\mathbf{x}}=$ Overall mean; $T_{i}=$ Effect of treatment $(j=1,2,3)$; $B_{j}=$ Effect of breed of ducks $(j=1,2) ;$ TB $_{i j}$ $=$ Interaction effect between breed of ducks and treatment and $E_{i j k}=$ Random error component assumed to be normally distributed.

\section{RESULTS AND DISCUSSION}

Productive performance of Mulard and Muscovy ducks during force feeding:

Results in Table 3 indicated that live body weight (LBW) of the Mulard ducks before the force feeding period (at 12 weeks of age), was $5.21 \%$ heavier than that of the Muscovy ducks (4147.6 vs.3942.2g, respectively). In contradiction El-Sayed and Mahrous (2013) found that LBW of Muscovy ducks before the force feeding (at 12 weeks of age) was 12.11\% heavier than that of the Mulard ducks (4563.67g vs. $4070.25 \mathrm{~g}$, respectively). However, after force feeding (at 14 weeks of age), the difference in LBW between Mulard and Muscovy ducks were significant (5371.6g vs. $5183.0 \mathrm{~g}$, respectively). Results in the present study may be due to LBW of Mulard ducks was higher by $205.4 \mathrm{~g}$ than Muscovy ducks at beginning of force feeding period (12 weeks of age), which became $188.6 \mathrm{~g}$ at the end of force feeding period (14 weeks of age). These results are in contradiction with El-Sayed and Mahrous (2013) who reported that after force feeding, the difference in LBW between Mulard and Muscovy ducks was not significant (5761.58 vs. $5676.53 \mathrm{~g}$, respectively). Improvement in LBW values were 29.87 and $18.99 \%$ for duckling using force feeding ration supplemented with (Avizyme enzyme and without avizyme) compared to those fed the control ration without force feeding (at 14 weeks of age). Interaction between duckling breed and force feeding was significantly affected live body weight during different experimental periods. Mulard ducklings was significantly higher LBW than Muscovy ducklings.

Results in Table 3 indicated that the difference in body weight gain (BWG) for Mulard ducks (1224.07g) after two weeks of force feeding force feeding period was insignificant when compared with that of Muscovy ducks (1240.83g). In contradiction with results obtained by Guy et al. (1995) who found that the BWG due to forced feeding was higher in Mulard ducks than in Muscovy ducks. Also, Chartrin et al. (2006) reported that force feeding induced a significant increase in body weight $(+30 \%)$. The 
increase in body weight was about $45 \%$ for Mulard ducks and $18 \%$ for Muscovy ducks. Moreover, Andre et al. (2007) showed higher weight gains for Mulard ducks than that of Muscovy ducks when force feeding was at the maximum of the ducks' ingestion potential. Also, El-Sayed and Mahrous (2013) who found that BWG for Mulard ducks after the force feeding period was significantly heavier (1516.1g) than Muscovy ducks (861.92g). These results may be due to feed efficiency for Muscovy ducks improved with increasing age in the period after 12 weeks of age. Similar trend was obtained for BWG values, which improvement of BWG values was 228.20 and $133.29 \%$ for duckling fed force feeding ration supplemented with (Avizyme enzyme and without avizyme enzyme) compared to those fed the control ration during force feeding (at 14 weeks of age). Interaction between duckling breed and force feeding was significantly affect on BWG gain during different experimental period.

\section{Feed conversion ratio (FCR):}

Results obtained in Table 3 indicated that cumulative feed conversion ratio (FCR,g feed ,g weight) values were significantly higher in Mulard ducks than in Muscovy ducks (12.08 vs. $9.99 \mathrm{~kg}$, respectively). The lower FCR value for Muscovy ducks indicates positive performance. In contradiction with results obtained by El-Sayed and Mahrous (2013) who reported that FCR for Mulard was (8.59) better than Muscovy (10.09) ducks. Interaction between duckling breed and force feeding had significantly effect on FCR ratio during different experimental period. The best values for FCR were recorded in force feeding with avizyme groups.

Table 3: Effect of force feeding $(\bar{x})$ and using avizyme on some productive traits for Mulard and Muscovy ducks at 14 weeks of age.

\begin{tabular}{|c|c|c|c|c|c|c|c|c|}
\hline \multirow{2}{*}{$\begin{array}{c}\text { Age } \\
\text { (weeks) }\end{array}$} & \multirow{2}{*}{ Breed } & \multicolumn{3}{|c|}{ Forced feeding } & \multirow[t]{2}{*}{ Av. } & \multicolumn{3}{|c|}{ Probability } \\
\hline & & Control & Avizyme & Without & & B & $\mathbf{T}$ & BT \\
\hline \multicolumn{9}{|c|}{ Live body weight ( $\mathrm{g}$ ) } \\
\hline \multirow{3}{*}{$14 w k$} & Mulard & 4549.0 & 6139.9 & 5426.0 & 5371.6 & * & ** & ** \\
\hline & Muscovy & 4527.3 & 5647.3 & 5374.3 & 5183.0 & & & \\
\hline & Av. & 4538.2 & 5893.6 & 5400.2 & & & & \\
\hline \multicolumn{9}{|c|}{ Body weight gain $(\mathrm{g})$} \\
\hline \multirow{3}{*}{$14 \mathrm{wk}$} & Mulard & 470.7 & 1990.2 & 1211.3 & 1224.07 & NS & ** & ** \\
\hline & Muscovy & 647.2 & 1678.7 & 1396.6 & 1240.83 & & & \\
\hline & Av. & 558.93 & 1834.43 & 1303.95 & & & & \\
\hline \multicolumn{9}{|c|}{ Feed intake (g / duckling) } \\
\hline \multirow{3}{*}{$14 w k$} & Mulard & 10500 & 10500 & 10500 & 10500 & & & \\
\hline & Muscovy & 10500 & 10500 & 10500 & 10500 & & & \\
\hline & Av. & 10500 & 10500 & 10500 & & & & \\
\hline \multicolumn{9}{|c|}{ Feed conversion ratio (g feed/g gain) } \\
\hline \multirow{3}{*}{$14 \mathrm{wk}$} & Mulard & 22.31 & 5.28 & 8.66 & 12.08 & ** & ** & ** \\
\hline & Muscovy & 16.22 & 6.25 & 7.51 & 9.99 & & & \\
\hline & Av. & 19.26 & 5.76 & 8.09 & & & & \\
\hline
\end{tabular}




\section{Carcass characteristics:}

Effect of force feeding and using avizyme on carcass parameters of ducks as percentage are shown in Table 4 Data demonstrated that the Mulard ducks were significantly higher in all carcass traits (live body weight, carcass, liver, total giblets, and edible parts \%) than Muscovy ducks. Moreover, Mulard ducks was insignificantly in liver and giblets percentage (4.75 and $7.75 \%)$ when compared with Muscovy ducks (4.43 and $7.36 \%)$. Force feeding was significantly $(P \leq 0.01)$ affected on all carcass characteristics. Carcass percentage were significantly increased by 6.64 and $1.93 \%$, respectively for duckling breed fed force feeding ration supplemented with (Avizyme and without avizyme) compared with the control. These results may be related to the significantly higher body weight for Mulard ducks $(5265.6 \mathrm{~g}$ ) than Muscovy ducks (4868.9g) after the force feeding period. Liver percentage were significantly increased by $\mathbf{1 3 8 . 7 5}$

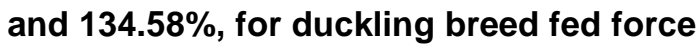
feeding ration supplemented with (Avizyme and without avizyme) compared with fed the control. Liver percentage increased due to duckling breed and force feeding respectively. Total edible parts percentage were significantly increased by 10.48 and $6.24 \%$, respectively for duckling breed fed ration supplemented with (Avizyme and without avizyme) compared with the control. Similar trend was obtained by El-Sayed and Mahrous (2013) who found that Mulard ducks had higher liver weights and liver percentage (362.38g and 5.99\%) than Muscovy ducks (320.90g and $5.50 \%$, respectively). However, the differences were not significant. In consistent with the same author, who found that Muscovy ducks had significantly higher carcass weight and percentage than Mulard ducks after the force feeding period $(3687.18 \mathrm{~g}$ and $65.10 \%$ vs. $3597.84 \mathrm{~g}$ and $62.45 \%$, respectively). Interaction between duckling breeds and force feeding had significantly effect on carcass traits during different all studied traits except with gizzard\% at 14 weeks of age.

\section{Chemical composition of ducks meat:}

Chemical composition of ducks meat after force-feeding are presented in Table 5 The difference in ether extract percentage of ducks meat between Mulard ducks and Muscovy ducks was not significant. while, the moisture, crude protein and ash percentage were significantly higher in Mulard ducks than Muscovy ducks. These results are in agreement with Mostafa (1989) compared the chemical composition of Mulard (Muscovy×Pekin) and Muscovy ducks and results were 77.28 vs. $77.36,18.69$ vs. $18.7,1.18$ vs. $1.19,1.14$ vs. 1.19 and 1.7 vs. 1.57 for moisture, protein, fat, ash and nitrogen free extract percentage, respectively. In contrast, Taboosha (2006) found that Muscovy ducks was high in crude protein, ether extract, ash and nitrogen free extract percentages compared to Mulard ducks. Also, the same author showed that, the differences between the breeds studied (Muscovy, Pekin, Khaki-campbell and their crosses) in their chemical composition traits were not significant except only for N.F.E. percentages, where the differences were highly significant. On the other hand, the interaction between duckling breeds and force-feeding on meat chemical composition of ducks was significant.

\section{Liver chemical composition :}

The chemical composition for liver after force-feeding (14 weeks of age) are shown in Table 6 Liver of Mulard ducks contained highly significant moisture, CP and ash percentages when compared to liver of Muscovy ducks. while, liver of Muscovy ducks contain high significant ether extract percentage compared to 
Table 4: Effect of force feeding $(\bar{x})$ and using avizyme on relative carcass organs (\%) for Mulard and Muscovy ducks at 14 weeks of age.

\begin{tabular}{|c|c|c|c|c|c|c|c|c|}
\hline \multirow{2}{*}{ Items } & \multirow{2}{*}{ Breed } & \multicolumn{3}{|c|}{ Forced feeding } & \multirow{2}{*}{ Av. } & \multicolumn{3}{|c|}{ Probability } \\
\hline & & Control & Avzime & Without & & B & $\mathbf{T}$ & BT \\
\hline \multirow{3}{*}{ LBW (g) } & Mulard & 3598.3 & 6565.0 & 5633.3 & 5265.6 & $\star *$ & $\star *$ & ** \\
\hline & Muscovy & 3551.7 & 6238.3 & 4816.7 & 4868.9 & & & \\
\hline & Av. & 3571.0 & 6401.7 & 5225.0 & & & & \\
\hline \multirow{3}{*}{$\begin{array}{l}\text { Carcass } \\
\text { weight } \%\end{array}$} & Mulard & 68.58 & 71.61 & 69.14 & 69.78 & * & * & ** \\
\hline & Muscovy & 66.41 & 72.11 & 68.44 & 68.98 & & & \\
\hline & Av. & 67.50 & 71.86 & 68.80 & & & & \\
\hline \multirow{3}{*}{ Liver\% } & Mulard & 2.60 & 5.88 & 5.75 & 4.75 & NS & $\star *$ & $\star *$ \\
\hline & Muscovy & 2.21 & 5.58 & 5.50 & 4.43 & & & \\
\hline & Av. & 2.40 & 5.73 & 5.63 & & & & \\
\hline \multirow{3}{*}{ Heart\% } & Mulard & 0.74 & 0.78 & 0.77 & 0.76 & NS & * & $* *$ \\
\hline & Muscovy & 0.84 & 0.59 & 0.71 & 0.71 & & & \\
\hline & Av. & 0.79 & 0.68 & 0.74 & & & & \\
\hline \multirow{3}{*}{$\begin{array}{c}\text { Gizzard } \\
\%\end{array}$} & Mulard & 2.18 & 2.26 & 2.27 & 2.24 & NS & NS & NS \\
\hline & Muscovy & 2.18 & 2.21 & 2.23 & 2.21 & & & \\
\hline & Av. & 2.18 & 2.23 & 2.25 & & & & \\
\hline \multirow{3}{*}{$\begin{array}{c}\text { Total } \\
\text { giblet } \%\end{array}$} & Mulard & 5.52 & 8.93 & 8.81 & 7.75 & NS & * & ** \\
\hline & Muscovy & 5.23 & 8.39 & 8.45 & 7.36 & & & \\
\hline & Av. & 5.38 & 8.66 & 8.63 & & & & \\
\hline \multirow{3}{*}{$\begin{array}{l}\text { Abdomin } \\
\text { al fat } \%\end{array}$} & Mulard & 1.48 & 2.46 & 2.67 & 2.20 & $\star \star$ & $\star \star$ & ** \\
\hline & Muscovy & 1.82 & 3.63 & 3.72 & 3.05 & & & \\
\hline & Av. & 1.65 & 3.05 & 3.20 & & & & \\
\hline \multirow{3}{*}{$\begin{array}{l}\text { Edible } \\
\text { part\% }\end{array}$} & Mulard & 74.11 & 80.54 & 77.95 & 77.54 & * & $\star *$ & ** \\
\hline & Muscovy & 71.65 & 80.50 & 76.90 & 76.35 & & & \\
\hline & Av. & 72.88 & 80.52 & 77.43 & & & & \\
\hline \multirow{3}{*}{$\begin{array}{l}\text { Intestine } \\
\text { weight } \%\end{array}$} & Mulard & 2.56 & 4.95 & 4.56 & 4.03 & NS & * & $* *$ \\
\hline & Muscovy & 3.25 & 5.75 & 5.32 & 4.78 & & & \\
\hline & Av. & 2.90 & 5.35 & 4.94 & & & & \\
\hline
\end{tabular}

LBW= live body weight, $P=$ Probability level, $N S=$ No significant, ${ }^{*}=P \leq 0.05,{ }^{* *}=P \leq 0.01$.

$B=$ Effect of breed, $T=$ Effect of treatment and $B T=$ Interaction effect between breed and treatment. 
A.A. El-Fiky, et al.,

Table 5: Effect of force feeding $(\bar{x})$ and using avizyme on meat chemical composition for Mulard and Muscovy ducks at 14 weeks of age.

\begin{tabular}{|c|c|c|c|c|c|c|c|c|}
\hline \multirow{2}{*}{ Items } & \multirow{2}{*}{ Breed } & \multicolumn{3}{|c|}{ Forced feeding } & \multirow{2}{*}{ Av. } & \multicolumn{3}{|c|}{ Probability } \\
\hline & & Control & Avzime & Without & & B & T & BT \\
\hline & Mulard & 51.54 & 52.24 & 52.33 & 52.04 & * & NS & ** \\
\hline \multirow[t]{3}{*}{ MO\% } & Muscovy & 52.65 & 54.86 & 54.54 & 54.02 & & & \\
\hline & Av. & 52.09 & 53.55 & 53.43 & & & & \\
\hline & Mulard & 14.37 & 15.97 & 15.76 & 15.37 & ** & ** & ** \\
\hline \multirow[t]{3}{*}{ CP\% } & Muscovy & 12.30 & 13.82 & 13.67 & 13.26 & & & \\
\hline & Av. & 13.33 & 14.89 & 14.72 & & & & \\
\hline & Mulard & 33.34 & 29.19 & 30.50 & 31.01 & NS & ** & ** \\
\hline \multirow[t]{3}{*}{ E.E.\% } & Muscovy & 30.94 & 29.62 & 30.18 & 30.24 & & & \\
\hline & Av. & 32.14 & 29.40 & 30.34 & & & & \\
\hline & Mulard & 2.58 & 2.45 & 2.48 & 2.50 & * & NS & ** \\
\hline \multirow[t]{2}{*}{ Ash\% } & Muscovy & 1.39 & 1.36 & 1.38 & 1.38 & & & \\
\hline & Av. & 1.98 & 1.90 & 1.93 & & & & \\
\hline
\end{tabular}

Mo $=$ Moisture, $\mathrm{CP}=$ Crude protein and E.E. $=$ Ether Extract.

$\mathrm{P}=$ Probability level, NS $=$ No significant, ${ }^{*}=\mathrm{P} \leq 0.05,{ }^{*}=\mathrm{P} \leq 0.01$.

$B=$ Effect of breed, $T=$ Effect of treatment and $B T=$ Interaction effect between breed and treatment.

liver of Mulard ducks. These results are in agreement with Hermier et al. (2003) who compared moisture (39.6 vs. 32.0), protein (9.65 vs. 7.29$)$ and ash (1.15 vs. 0.92) percentages for Common ducks (Anas platyrhynchos) and found significantly higher difference than Muscovy ducks. While, the Muscovy ducks had significantly higher lipids percentage than Common ducks $(61.90$ vs. $50.10 \%$ ). In addition, Attia (2015) indicated that percentages of moisture, protein, fat and ash for breast meat after force-feeding at 14 weeks of age were $49.61,12.15, \quad 35.90$ and $0.76 \%$ for Muscovy ducks and 60.94, 16.85, 19.66 and $\mathbf{0 . 8 6}$ for Mulard ducks, respectively. Moreover, interaction effect between duckling breeds and force-feeding on chemical composition of liver was significant. Results in Table (6) indicated that force feeding for Muscovy ducks (light body weight) caused a considerable modifications in the chemical composition parameter of the liver, increasing the percentage of fat content and reducing the water content and ash content compared to Mulard (heavy body weight). These results are in unanimous agreement with the finding of Chartrin et al. (2006) and Ferial and Abou Arab - (2010) who found that force feeding caused a considerable modifications in the chemical composition parameter of the liver, increasing the percentage of fat content and reducing the protein content water content and ash content. Data in Table 7 shows that liver of Muscovy ducks was high significant in LDL (mg/dl) and cholesterol (mg/dl) and insignificant total lipids weight (mg/dl), triglycerides ( $\mathrm{mg} / \mathrm{dl})$ and HDL (mg/dl) compared to the other breed (Mulard duck). These results are in agreement with Hermier et al. (2003) who found that accumulation of lipids in hepatic statuses depended on the genotype; the total lipid amount 
increased 85-fold in the Muscovy duck and 50-fold only in the common duck. In consequence, lipids accounted for more than $60 \%$ of liver weight in the Muscovy duck, whereas fatty liver of the common duck contained only $\mathbf{5 0 \%}$ lipids. Also,
Table 6 showed that interaction between duckling breeds and force-feeding on liver lipids parameters were insignificant during different studied except with cholesterol and LDL (mg/dl).

Table 6: Effect of force feeding $(\bar{x})$ and using avizyme on liver chemical composition and liver parameters for Mulard and Muscovy ducks at 14 weeks of age.

\begin{tabular}{|c|c|c|c|c|c|c|c|c|}
\hline \multirow{2}{*}{ Items } & \multirow{2}{*}{ Breed } & \multicolumn{3}{|c|}{ Forced feeding } & \multirow{2}{*}{ Av. } & \multicolumn{3}{|c|}{ Probability } \\
\hline & & Control & Avizyme & Without & & B & $\mathbf{T}$ & BT \\
\hline \multicolumn{9}{|c|}{ Liver chemical composition } \\
\hline \multirow{4}{*}{ MO\% } & Mulard & 59.70 & 61.96 & 60.88 & 60.85 & $* *$ & * & ** \\
\hline & Muscovy & 47.74 & 49.17 & 48.55 & 48.49 & & & \\
\hline & Av. & 53.72 & 55.57 & 54.72 & & & & \\
\hline & Mulard & 17.34 & 16.22 & 15.62 & 16.39 & ** & NS & $* *$ \\
\hline \multirow[t]{3}{*}{ СР\% } & Muscovy & 11.63 & 12.59 & 12.33 & 12.18 & & & \\
\hline & Av. & 14.48 & 14.41 & 13.98 & & & & \\
\hline & Mulard & 20.48 & 18.44 & 19.37 & 19.43 & $\star \star$ & * & $* *$ \\
\hline \multirow[t]{3}{*}{ E.E.\% } & Muscovy & 36.48 & 34.66 & 35.76 & 35.63 & & & \\
\hline & Av. & 28.48 & 26.55 & 27.57 & & & & \\
\hline & Mulard & 0.82 & 0.87 & 0.85 & 0.85 & $\star \star *$ & $* *$ & $* *$ \\
\hline \multirow[t]{2}{*}{ Ash\% } & Muscovy & 0.74 & 0.78 & 0.76 & 0.77 & & & \\
\hline & Av. & $0.78^{c}$ & 0.83 & 0.81 & & & & \\
\hline \multicolumn{9}{|c|}{ liver parameters } \\
\hline \multirow{3}{*}{$\begin{array}{l}\text { Total lipids } \\
\text { (mg/dl }\end{array}$} & Mulard & 425.68 & 420.79 & 423.62 & 423.37 & NS & NS & NS \\
\hline & Muscovy & 446.42 & 442.07 & 444.13 & 444.21 & & & \\
\hline & Av. & 436.05 & 431.43 & 433.87 & & & & \\
\hline \multirow{3}{*}{$\begin{array}{l}\text { Cholesterol } \\
\text { (mg/dl) }\end{array}$} & Mulard & 200.75 & 185.66 & 187.67 & 191.36 & ** & ** & ** \\
\hline & Muscovy & 262.65 & 200.61 & 238.25 & 233.84 & & & \\
\hline & Av. & 231.70 & 193.14 & 212.96 & & & & \\
\hline \multirow{3}{*}{ LDL (mg/dl) } & Mulard & 65.51 & 60.46 & 63.48 & 63.15 & ** & NS & $* *$ \\
\hline & Muscovy & 80.41 & 77.85 & 79.13 & 79.13 & & & \\
\hline & Av. & 72.96 & 69.16 & 71.31 & & & & \\
\hline \multirow{3}{*}{ HDL (mg/dl) } & Mulard & 77.47 & 75.54 & 76.65 & 76.55 & NS & NS & NS \\
\hline & Muscovy & 83.40 & 80.51 & 82.98 & 82.30 & & & \\
\hline & Av. & 80.44 & 78.03 & 79.82 & & & & \\
\hline \multirow{3}{*}{$\begin{array}{l}\text { Triglyceride } \\
\text { (mg/dl) }\end{array}$} & Mulard & 5.47 & 5.34 & 5.38 & 5.40 & NS & NS & NS \\
\hline & Muscovy & 6.11 & 5.58 & 5.80 & 5.83 & & & \\
\hline & Av. & 5.79 & 5.46 & 5.59 & & & & \\
\hline
\end{tabular}




\section{Blood constituents:}

Results of Table 7 showed the effect of breed on plasma blood parameter for duck slaughtered at 14 weeks of age (After force-feeding).. Blood plasma for Mulard ducks was highly significant in total protein (g/dl), albumin (g/dl), globulin (g/dl), A/G ratio and insignificant in LDL (mg/dl) and AST (U/L) when compared to the Muscovy ducks. On contrary,the difference in blood plasma of Muscovy was highly significant in total lipids (mg/dl), cholesterol ( $\mathrm{mg} / \mathrm{dl})$, triglycerides (mg/dl), HDL (mg/dl), glucose $(\mathrm{mg} / \mathrm{dl})$ and insignificant in ALT (U/L), when compared to Mulard duck. Values of blood plasma parameters for Mulard ducks took the same direction before force-feeding with change in some of the values such as (cholesterol, HDL and ALT). These results are in agreement with Attia (2015) who reported that the levels of plasma total cholesterol after force-feeding at 14 weeks of age were 285.49 and $258.08 \mathrm{mg} / \mathrm{dl}$, for Muscovy and Mulard ducks, respectively. On the other hand, El-Sayed and Mahrous (2013) found that Mulard ducks recorded significantly higher difference in cholesterol (128.34 vs. 116.211) and insignificantly higher HDL (39.15 $\pm 5.52 \mathrm{v}$. $32.36 \pm 4.94)$ values under forced feeding compared with Muscovy ducks. Also, these results are consistent with Chartin et al. (2006) who found that after forced feeding Muscovy ducks had lower levels of plasma phospholipids and total cholesterol than Mulard ducks. On the other hand, these results are in agreement with the same author, who found that Mulard ducks recorded insignificantly higher LDL value than Muscovy ducks. Moreover, interactions effect between duckling breeds and force feeding on blood parameters were significant different in all studied traits except with LDL (mg/dl), AST (U/L) and ALT (U/L).

\section{Economical efficiency:}

Results of Table 8 showed the economic efficiency for ducks at 14 weeks of age (After force-feeding). Concerning breed effect, regardless of body weight group effect, the Mulard ducks had the highest net revenue (949 and 849/L.E) and economic efficiency value (571.7 and 511.4) compared to Muscovy ducks for avizyme and without avizyme, respectively because Mulard ducks had the highest body weight and the biggest liver when compared with Muscovy ducks these result was in agreement with Attia (2015).

\section{CONCOLUSION}

It could be concluded that Mulard ducks are suitable for force feeding than Muscovy ducks to achieve a fast increase in body weight in short time. Also, to have a high quality of fatty liver which have a high marketing value indoors and outdoors. Mulard ducks had the highest net revenue and economic efficiency value compared to the Muscovy ducks. Using dietary avizyme addition in force feeding recorded the best in economical efficiency value compared to that of without avizyme and control groups, respectively. 
Table 7: Effect of force feeding ( $\bar{x})$ and using avizyme on blood parameters for Mulard and Muscovy ducks at 14 weeks of age.

\begin{tabular}{|c|c|c|c|c|c|c|c|c|}
\hline \multirow{2}{*}{ Items } & \multirow{2}{*}{ Breed } & \multicolumn{3}{|c|}{ Forced feeding } & \multirow{2}{*}{ Av. } & \multicolumn{3}{|c|}{ Probability } \\
\hline & & Control & Avizyme & Without & & B & $\mathbf{T}$ & BT \\
\hline \multirow{3}{*}{$\begin{array}{l}\text { Total } \\
\text { protein } \\
\text { (g/ dl) }\end{array}$} & Mulard & 5.73 & 5.80 & 5.74 & 5.76 & $* *$ & NS & ** \\
\hline & Muscovy & 4.76 & 4.81 & 4.78 & 4.78 & & & \\
\hline & Av. & 5.25 & 5.31 & 5.26 & & & & \\
\hline \multirow{3}{*}{$\begin{array}{l}\text { Albumin } \\
\text { (g/ dl) }\end{array}$} & Mulard & 3.19 & 3.27 & 3.21 & 3.22 & ** & NS & ** \\
\hline & Muscovy & 2.55 & 2.61 & 2.57 & 2.57 & & & \\
\hline & Av. & 2.87 & 2.94 & 2.89 & & & & \\
\hline \multirow{4}{*}{$\begin{array}{l}\text { Globulin } \\
\text { (g/ dl) }\end{array}$} & Mulard & 2.55 & 2.54 & 2.52 & 2.53 & * & NS & $* *$ \\
\hline & Muscovy & 2.21 & 2.20 & 2.21 & 2.20 & & & \\
\hline & Av. & 2.73 & 2.36 & 2.36 & & & & \\
\hline & Mulard & 1.26 & 1.30 & 1.27 & 1.28 & * & NS & $\star *$ \\
\hline \multirow[t]{3}{*}{ A/G ratio } & Muscovy & 1.15 & 1.18 & $1.16 \pm 0.06$ & 1.17 & & & \\
\hline & Av. & 1.21 & 1.24 & 1.22 & & & & \\
\hline & Mulard & 2557.24 & 2552.25 & 2555.17 & 2554.9 & ** & NS & ** \\
\hline \multirow{2}{*}{$\begin{array}{l}\text { Total lipids } \\
\text { (mg/dl) }\end{array}$} & Muscovy & 2661.08 & 2655.36 & 2659.39 & 2658.6 & & & \\
\hline & Av. & 2609.16 & 2603.80 & 2607.28 & & & & \\
\hline \multirow{3}{*}{$\begin{array}{c}\text { Cholesterol } \\
\text { (mg/dl) }\end{array}$} & Mulard & 259.75 & 255.66 & 257.67 & 257.69 & $* *$ & NS & $* *$ \\
\hline & Muscovy & 290.27 & 285.61 & 287.18 & 287.69 & & & \\
\hline & Av. & 275.00 & 270.63 & 272.42 & & & & \\
\hline \multirow{3}{*}{$\begin{array}{l}\text { LDL } \\
\text { (mg/dl) }\end{array}$} & Mulard & 108.44 & 103.23 & 105.69 & 105.78 & NS & NS & NS \\
\hline & Muscovy & 97.30 & 93.92 & 95.59 & 95.60 & & & \\
\hline & Av. & 102.87 & 98.57 & 100.64 & & & & \\
\hline \multirow{3}{*}{$\begin{array}{l}\mathrm{HDL} \\
\text { (mg/dl) }\end{array}$} & Mulard & 122.51 & 118.87 & 120.65 & 120.67 & ** & NS & ** \\
\hline & Muscovy & 150.66 & 145.54 & 149.00 & 148.40 & & & \\
\hline & Av. & 136.58 & 132.21 & 134.82 & & & & \\
\hline \multirow{3}{*}{$\begin{array}{l}\text { Triglyceride } \\
\text { (mg/dl) }\end{array}$} & Mulard & 195.24 & 170.43 & 186.74 & 184.14 & $\star *$ & $* *$ & ** \\
\hline & Muscovy & 245.36 & 205.44 & 229.55 & 226.78 & & & \\
\hline & Av. & 220.30 & 187.94 & 208.15 & & & & \\
\hline \multirow{4}{*}{$\begin{array}{l}\text { AST } \\
\text { (U/L) }\end{array}$} & Mulard & 640.43 & 635.00 & 637.62 & 637.68 & NS & NS & NS \\
\hline & Muscovy & 604.48 & 600.51 & 603.19 & 602.72 & & & \\
\hline & Av. & 622.45 & 617.76 & 620.41 & & & & \\
\hline & Mulard & 111.32 & 108.38 & 110.38 & 110.05 & NS & NS & NS \\
\hline \multirow{2}{*}{$\begin{array}{l}\text { ALT } \\
\text { (U/L) }\end{array}$} & Muscovy & 112.18 & 110.48 & 111.60 & 111.42 & & & \\
\hline & Av. & 111.75 & 109.43 & 110.02 & & & & \\
\hline \multirow{3}{*}{$\begin{array}{l}\text { Glucose } \\
\text { (mg/dl) }\end{array}$} & Mulard & 119.89 & 126.52 & 125.61 & 124.00 & ** & NS & ** \\
\hline & Muscovy & 172.53 & 176.71 & 175.36 & 174.86 & & & \\
\hline & Av. & 146.21 & 151.61 & 150.48 & & & & \\
\hline
\end{tabular}


A.A. El-Fiky, et al.,

Table 8 : Effect of force-feeding on economic efficiency for Mulard and Muscovy ducks at 14 weeks of age.

\begin{tabular}{|c|c|c|c|c|c|c|}
\hline \multirow{2}{*}{ Item } & \multicolumn{3}{|c|}{ Muscovy } & \multicolumn{3}{|c|}{ Mulard } \\
\hline & Control & Avizyme & Without & Control & Avizyme & Without \\
\hline LBW (kg.) & 3.552 & 5.674 & 5.374 & 3.598 & 6.140 & 5.426 \\
\hline${ }^{1}$ Cost of F.I /L.E & 71 & 71 & 71 & 81 & 81 & 81 \\
\hline${ }^{2}$ Cost of F.I. IL.E & 40 & 40 & 40 & 40 & 40 & 40 \\
\hline Total cost of F.I. IL.E & 111 & 111 & 111 & 121 & 121 & 121 \\
\hline${ }^{3}$ Fixed costs /L.E & 45 & 45 & 45 & 45 & 45 & 45 \\
\hline Total costs/L.E & 156 & 156 & 156 & 166 & 166 & 166 \\
\hline Liver weight (kg) & 78.3 & 348 & 265 & 93.3 & 386 & 323 \\
\hline Price of liver /L.E & - & 520 & 400 & - & 540 & 500 \\
\hline${ }^{4}$ (Magrite weight) gm & - & 890 & 834.90 & - & 1200 & 1000 \\
\hline Price of magrite /L.E & - & 400 & 380 & - & 500 & 450 \\
\hline Price of neck /L.E & - & 25 & 25 & - & 25 & 25 \\
\hline Price of thigh muscles /L.I & - & 40 & 40 & - & 50 & 40 \\
\hline${ }^{5}$ Total returns & 140 & 985 & 845 & 144 & 1115 & 1015 \\
\hline${ }^{6}$ Net revenue IL.E & -16 & 829 & 689 & -22 & 949 & 849 \\
\hline${ }^{7}$ Economic efficiency\% & -10.26 & 531.4 & 441.7 & -13.25 & 571.7 & 511.4 \\
\hline
\end{tabular}

1=cost of Feed intake before force feeding at 12 weeks of age, 2=cost of Feed intake after force feeding at 14 weeks of age, 3= Fixed costs /L.E = Price of day old chicks $+30 \%$ of feed cost, $4=$ Breast muscles weight, $5=$ Sum of revenue of (liver + magrite + thigh muscles weight), $6=$ Total returnes IL.E - Total costs IL.E. and $7=$ Net revenue/Total costs $* 100$.

\section{REFERENCES}

Andre, J.M., G. b. Guy, K. GontierLatonnelle, M.D. Bernadet, B. Davail, R. Hoo-Paris and S. Davail (2007). Influence of lipoproteinlipase activity on plasma triacylglycerol concentration and lipid storage in three genotypes of ducks. Comparative Biochemistry and Physiology, Part A, 148: 899-902.
A.O.A.C., Association of Official Agricultural Chemists (1995). Official Methods of Analysis. $16^{\text {th }}$-ed. Assoc. Off. Anal. Chem., Washington, DC.

Attia, M.B.M. (2015). Studies on fatty liver syndrome in ducks. Ph. D. Thesis. Fac. of Agric. Sci. Al-Azhar University.

Chartrin, P., M.D. Bernadet, G. Guy, J. Mourot, J.F. Hocquette, N. Rideau, M.J. Duclos, and E. Baeza. (2006). 
Does force feeding enhance genotype effects on liver ability for lipogenesis and lipid secretion in ducks. comprative biochemistry and physiology, part A (145): 390-396.

El-Sayed, M. Y., and U.E. Mahrous (2013). Influence of force feeding on productive performance traits, foie gras production, blood parameters, internal organs, carcass traits, and mortality rate in two breeds of ducks. World Academy of Science, Engineering and Technology Vol:7 2013-09-03.

FAO STAT (2009). Statistics dvision, food and agriculture organization, UNO, Rome,Italy.

Source:www.faostat.fao.org

Ferial, M.A.S. and E.A. Abou Arab (2010). Chemical properties, microbiological quality and sensory evaluation of chicken and duck liver paste (Foie Gras). Grasas Y. Acites, 61 (2): 126135.

Folch, J., M. Lee and G.H. Sloane-Stacey (1990). A Simple method for the isolation and purification of total lipids from animal tissues. J. Biol. Chem. 226: 497-509.

Guemene, D and G. Guy (2004). The past, present and future of force feeding and "foie gras" production World's Poultry Science Journal 60:211-222.

Guy, G., D. R. Pailley and D. Gourichon (1995). Comparison of geese, Mulard duck and Muscovy duck after cramming. Annales de Zootechnie, 44: 297-305.

Hermier, D., G. Guy, S. Gullaumin, S. Davail, J.M. Ander and R. Hoo-Paris (2003). Differential channeling of liver lipid in relation to susceptibility to hepatic steatosis in two species of ducks. Comparative Bioch. and Physiol. Part B (135): 663-675.

Hermier, D., D. Rousselot-Pailley, R. Presson and Sellier (1994). Influence of Orotic and Estrogen on Hepatic Lipid Storage and Secretion in The Goose Susceptible to Liver Statosis. Biochim. Biophys. Act. 1211: 97-106.

Mostafa, M.E.Y. (1989). Genetical and physiological studies on duck. M. Sc. Thesis, Fac. Agric., Kafer EL-Sheikh, Tanta Univ.

Rowida, M. Riad, T.S.T. Seleem and D.S.E. Mohamed (2010). The relation between type of mating and reproductive performance of rabbit under egyptian condition. The $6^{\text {th }}$ Inter. Con .on Rabbit Prod. in Hot Clim., Assuit, Egypt, 413- 426.

SAS. (2001). SAS User's Guide : Statistics. $9^{\text {th }}$, pp. Edition SAS Institute Inc.,Cary . NC., USA.

Taboosha, M. F. (2006). Effect of crossing different strains of ducks on some productive traits, M. Sc. Thesis, Animal Production Department, Fac. Of Agric. AL- Azhar Univ., Egypt. 
دراسات على إنتاج الكبد المسمن في البط تحت الظروف المصرية

عبد المنعم عبد الحليم الفقى (1) ، جمال عبد الستار زناتي (1) ، وائل على حسن على (2) ،

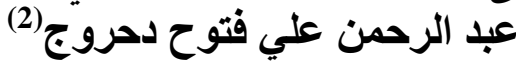

(1) قسم إنتاج الدواجن والأسماك ـ كلية الزراعة - جامعه المنوفيه ـ مصرح.

(2) قسم بحوث تربية الارانب والرومي والطيور المانية ـ معهل يحوث الانتاج الحبوانى ـ مركز البحوث الزراعية - وزارة

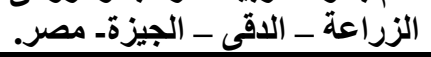
الملخص العربي المبري

أجريت هذه ألتجربة بهاف دراسة تأثير السلالة (المولر والمسكوفى) قبل التز غيط وبعده على وزن الجسم

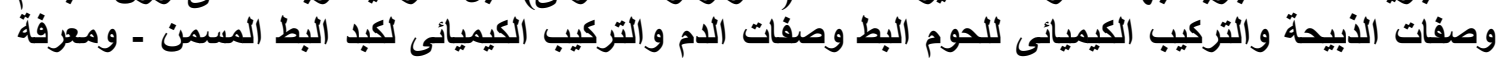

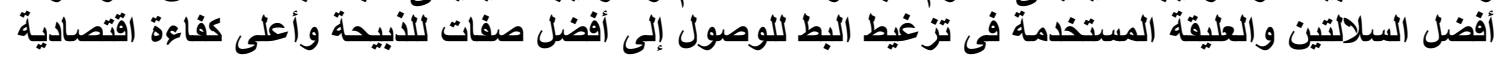

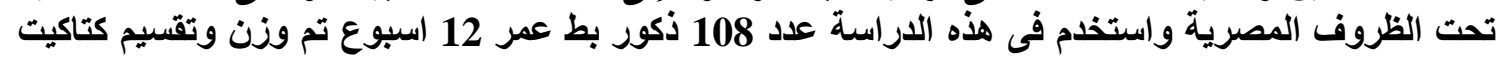

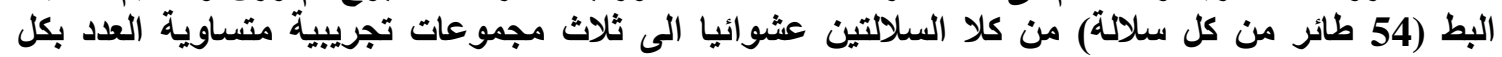

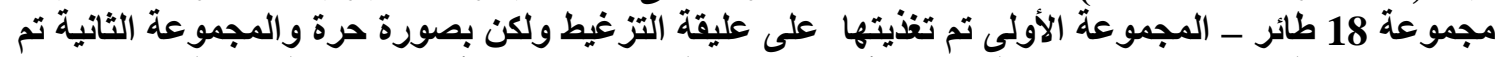

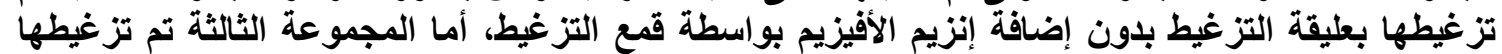

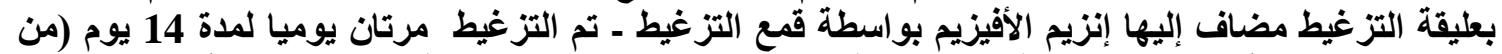

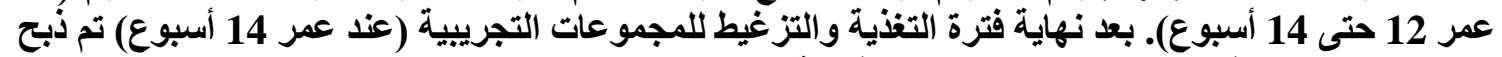
كل الطيور (المسكوفى والمولر) لتقير صفات الذبيحة و التحليل الكيميائى للحوم البط.

$$
\text { وأظهرت النتائج الآتى: الطئ }
$$

ـ البط المولر كان أعلى معنويا فى معدل الزيادة الوزنية مقارنة بالبط المسكوفى خلال فترة التزغيط (12 - 14 (اسبوع). ـ ـلوحظ زيادة معنوية في الأوزان المطلقة والنسبية في وزن الجسم (جرام) والذبيحة (جرام , \% \%) والكبد

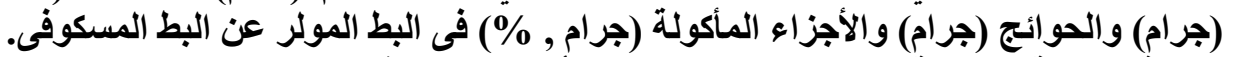

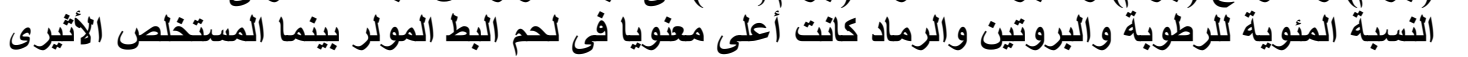

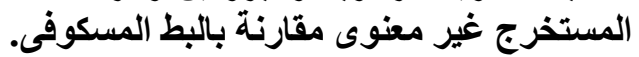

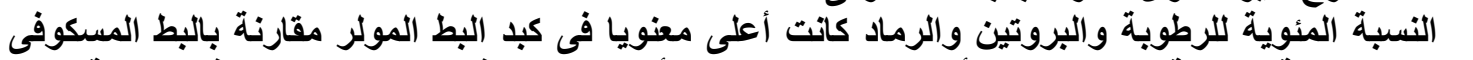

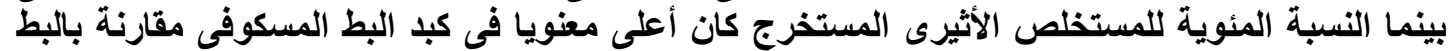

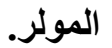
كبل البط المسكوفى كان أعلى معنويا فى البروتين الدهنى منذفض الكثافة والكوليسترول وغير معنويا فى لئى

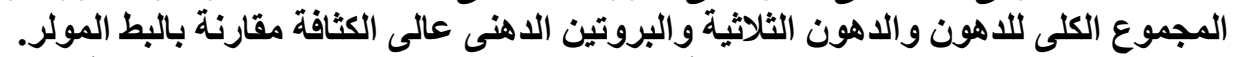

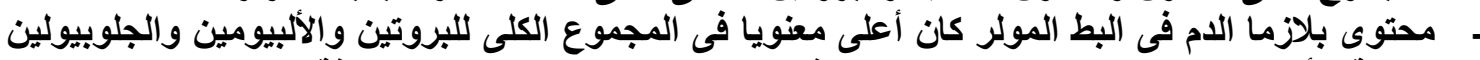

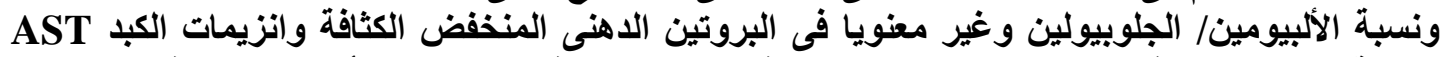

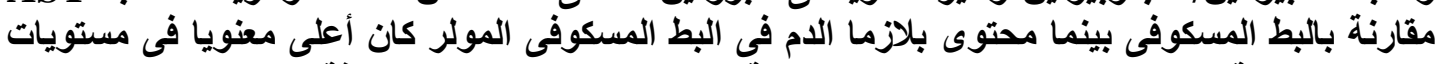

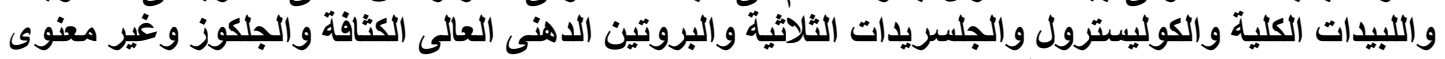
في انزيمات الكبد ALT مقارنة بالبط المولر.

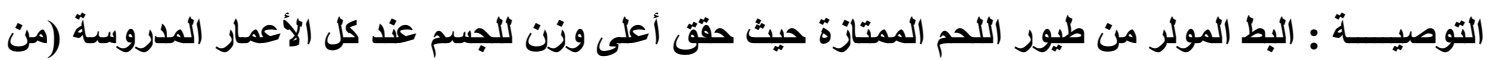

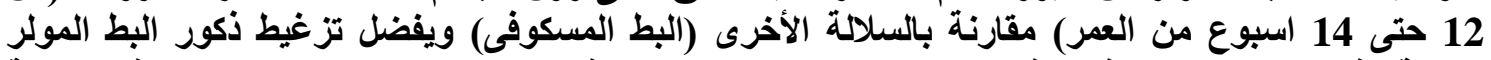

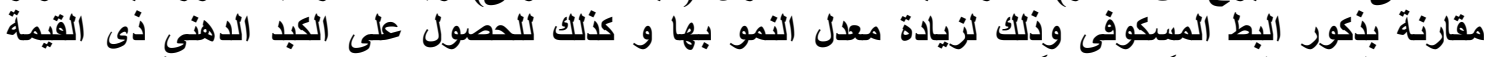

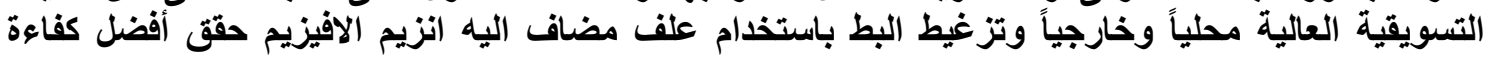
اقتصادية مقارنة بمجموعة البط بدون اضافة انزيم والكنترول. 


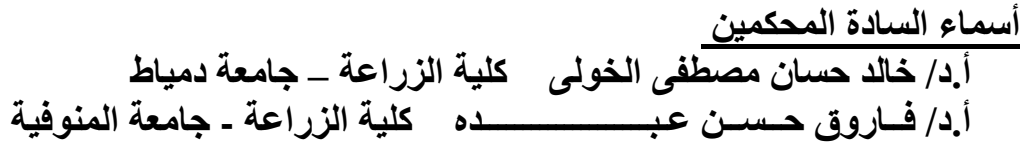

